\title{
EFFECT OF LIGNIN-CONTAINING MEDIA ON GROWTH OF MEDICINAL MUSHROOM LENTINULA EDODES
}

\author{
Natalja Matjuškova ${ }^{1,2}$, Laura Okmane ${ }^{1}$, Dzintra Zaljā1,2, Linda Rozenfelde ${ }^{1}$, \\ Māris Puḳe ${ }^{3}$, Irēna Krūma ${ }^{3}$, Nikolajs Vederṇikovs ${ }^{3}$, and Alexander Rapoport ${ }^{1, \#}$ \\ ${ }^{1}$ Institute of Microbiology and Biotechnology, University of Latvia, Jelgavas iela 1, Riga, LV-1004, LATVIA; \\ ${ }^{2}$ Faculty of Biology, University of Latvia, Jelgavas iela 1, Riga, LV-1004, LATVIA \\ ${ }^{3}$ Latvian State Institute of Wood Chemistry, Dzērbenes iela 27, Riga, LV-1006, LATVIA \\ \# Corresponding author, rapoport@mail.eunet.lv
}

Contributed by Alexander Rapoport

\begin{abstract}
The effect of lignocellulose and lignin on growth of mycelium of mushroom Lentinula edodes and laccase activity in cultivation medium was studied. It was shown that cultivation of L. edodes mycelium in liquid nutrient medium with addition of $0.25-0.5 \%$ of kraft lignin increased mycelium biomass yield approximately two times compared with reference conditions without addition of lignin. Similar results were obtained in experiments in which $0.5 \%$ lignocellulose that remained after obtaining furfural, and $0.5 \%$ lignin that remained after obtaining furfural and glucose from wheat straw, were added to the nutrient medium. This effect was greater in the conditions of cultivation with good aeration, compared with static culture. Laccase activity in medium increased after addition of wheat straw lignocellulose or lignin only in the case of mycelium cultivation with aeration. In the case of mushroom cultivation on solid nutrient medium, addition of wheat straw lignocellulose and lignin promoted growth of mycelium only during the first 7 days of cultivation.
\end{abstract}

Key words: Lentinula edodes, mycelium, lignocellulose, lignin, laccase.

\section{INTRODUCTION}

Paper and bioethanol industries produce large amounts of waste that contains lignin (Cotana et al., 2014). Its biodegradation to $\mathrm{CO}_{2}$ and $\mathrm{H}_{2} \mathrm{O}$ can be achieved by the use of mushroom Lentinula edodes (Leisola et al., 2012). This mushroom is widely used in traditional Chinese medicine (Matjuškova and Raipulis, 1999). It has immunomodulating and anticancerogenic characteristics (Kang, 2013). At present much attention is being paid to the cultivation of mycelium of this mushroom, which can be used as a zinc source in various diets (Turło et al. 2007). It was shown that dry mycelium possesses hepatoprotective properties (Sasidharan et al. 2010). This mushroom produces also a ligninolytic enzyme complex that includes laccases and peroxidases (Raaska, 1993; Ward et al., 2003). All enzymes of this complex are very interesting because of their possible biotechnological applications (Sweeney and $\mathrm{Xu}, 2012$ ). Use of $L$. edodes presents a very interesting biotechnological approach because it simultaneously offers two solutions: efficient lignin-containing wastes biodegradation and an efficient approach for $L$. edodes biomass production. This biomass can be thereby used as a source of biologically active compounds for the pharmaceutical industry. One of the lignin-containing wastes is wheat straw, which is produced in large amounts yearly in agricultural farms. Wheat straw may contain up to $23 \%$ lignin (Salvachśa, 2011).

The main goal of this study was to evaluate Lentinula edodes mushroom mycelium cultivation using lignocellulose and lignin waste obtained after furfural and glucose production from wheat straw.

\section{MATERIALS AND METHODS}

In this study we used the mushroom strain Lentinula edodes DSM 3565 received from the German Collection of Microorganisms and Cell Cultures. Cultivation of this mushroom was performed in liquid medium (28 days) and on solid medium (16 days) at $+22{ }^{\circ} \mathrm{C}$. Liquid nutrient medium was prepared on the basis of 2 times dilution of Malt Extract Broth (Biolife, Italy). To prepare solid nutrient medium the same diluted liquid medium was used with the addition of $20 \mathrm{~g} / \mathrm{l}$ agar. 
Cultivation of $L$. edodes mycelium in liquid nutrient medium was performed in $250 \mathrm{ml}$ flasks containing $75 \mathrm{ml}$ of medium with two variants: on an orbital shaker at $140 \mathrm{rpm}$ (aeration conditions) and in static conditions (without shaking). At the beginning of cultivation each flask was inoculated with two mycelium disks. After termination of mushroom cultivation, all flasks were filtered (two times) in sterile conditions to separate mycelium from cultural medium. Mycelium was washed two times with sterile distilled water. Then it was dried at $45^{\circ} \mathrm{C}$ and biomass yield was determined. Filtrates were stored at $-20^{\circ} \mathrm{C}$ until determination of laccase activity.

Petri plates were used for cultivation of mushroom on solid nutrient medium. In this case the central part of each Petri plate was inoculated with mycelium previously grown for ten days. A sterile metal hollow tubule with diameter 0.7 $\mathrm{mm}$ was used for inoculation. Mycelium colonies were measured daily.

Liquid and solid nutrient media were supplemented with wheat straw lignocellulose that remained after production of furfural or with wheat straw lignin that remained after production of furfural and glucose. In some experiments kraft lignin (Sigma-Aldrich Chemistry) was added to liquid and solid nutrient media.

Laccase activity was determined by spectrophotometry at $\lambda=436 \mathrm{~nm}$ using the 2,2'-azino-bis(3-ethylbenzothiazoline6-sulphonic acid (Sigma-Aldrich Chemistry) method (Niku-Paavola et al., 1990).

Experiments were conducted at least in triplicate. Results were expressed as means $\pm \mathrm{SD}$.

\section{RESULTS}

\section{Lentinula edodes mycelium growth in liquid nutrient media}

L. edodes mycelium cultivation in liquid medium containing commercial kraft lignin. We determined the effect of addition of kraft lignin at concentrations $0.05 \%, 0.25 \%$, $0.5 \%, 1.0 \%$, and $2.5 \%$ in liquid medium on L. edodes mycelium formation. These experiments were performed in flasks with shaking (140 rpm) and without shaking. The obtained results are shown in Table 1. Addition of lignin in concentration $0.25-0.5 \%$ increased mycelium biomass yield approximately two times compared with yield in conditions without lignin addition, for cultivation with and without shaking. Addition of $2.5 \%$ lignin to nutrient medium led to strong suppression of mycelium growth also in both cases (with or without shaking). Mycelium growth was related with decrease of nutrient medium $\mathrm{pH}$ from 7 to a lowest value of 3.5 .

Lentinula edodes mycelium cultivation in liquid medium containing wheat straw lignocellulose (after production of furfural) and remaining lignin (after production of furfural and glucose). We determined the effect of addition to liquid
Table 1

EFFECT OF KRAFT LIGNIN ADDITION TO THE NUTRIENT MEDIUM ON YIELD OF LENTINULA EDODES MYCELIUM

\begin{tabular}{c|c|c}
\hline \multirow{2}{*}{$\begin{array}{c}\text { Kraft lignin } \\
\text { concentration, }\end{array} \%$} & \multicolumn{2}{|c}{ Mycelium yield, g } \\
\cline { 2 - 3 }$\%$ & $\begin{array}{c}\text { Cultivation with shaking } \\
(140 \mathrm{rpm})\end{array}$ & $\begin{array}{c}\text { Static cultivation } \\
\text { (without shaking) }\end{array}$ \\
\hline 0.00 & $0.071 \pm 0.001$ & $0.083 \pm 0.008$ \\
0.05 & $0.096 \pm 0.002$ & $0.146 \pm 0.003$ \\
0.25 & $0.169 \pm 0.004$ & $0.128 \pm 0.006$ \\
0.50 & $0.163 \pm 0.002$ & $0.134 \pm 0.007$ \\
1.00 & $0.039 \pm 0.001$ & $0.043 \pm 0.001$ \\
2.50 & $0.006 \pm 0.001$ & $0.007 \pm 0.000$ \\
\hline
\end{tabular}

The results represent the mean \pm standard deviation of at least three independent experiments.
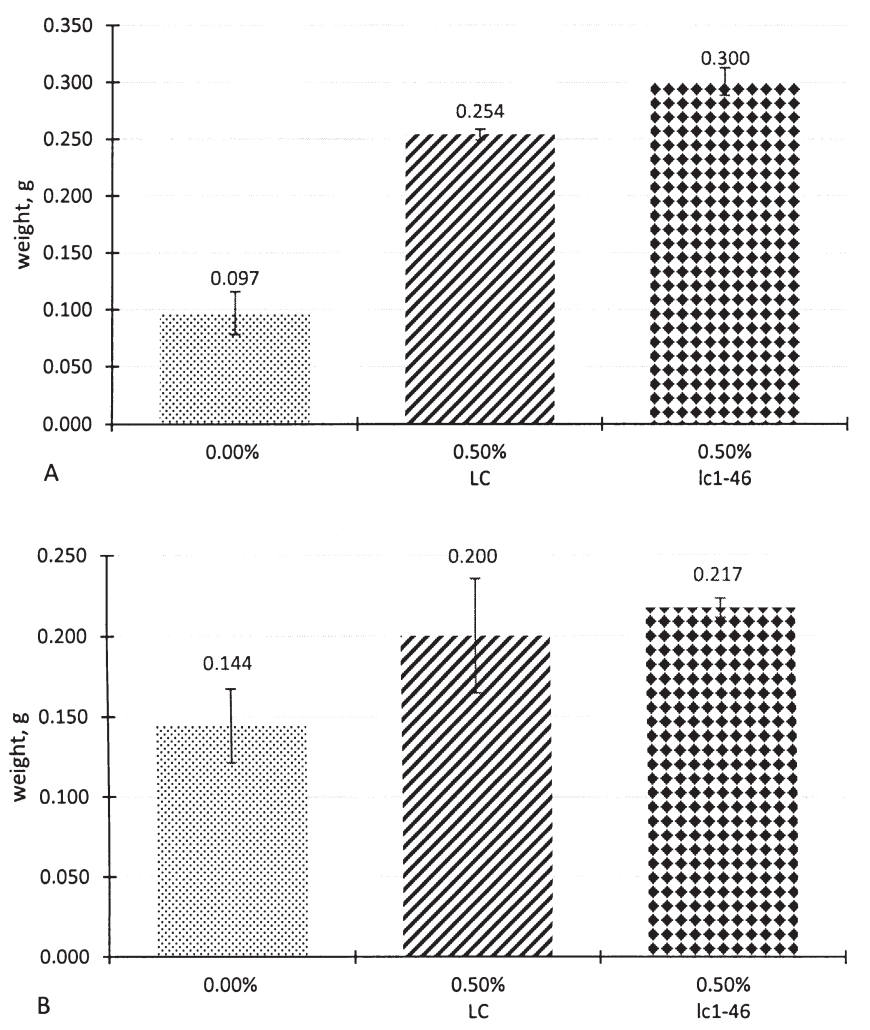

Fig. 1. Effect of wheat straw lignocellulose $(0.50 \%)$ or lignin $(0.50 \%)$ addition on yield of Lentinula edodes mycelium. Cultivation with shaking (140 rpm) (A) or in static conditions without shaking (B). Bars represent standard deviation.

nutrient medium of lignocellulose which remained after furfural production from wheat straw and of addition of lignin which remained after furfural and glucose production from wheat straw. The results of these experiments are shown in Figure 1. Addition to nutrient medium of both compounds (lignocellulose or lignin) at optimum concentration of kraft lignin addition $(0.5 \%)$ led to increase of mycelium yield. This effect was stronger in the case of cultivation with good aeration (shaking at $140 \mathrm{rpm}$ ) than in static culture. The yield of mycelium biomass in cultivation with 
Table 2

LACCASE ACTIVITY IN THE CULTIVATION MEDIUM AFTER 28 DAYS OF LENTINULA EDODES MYCELIUM GROWTH IN AERATION (WITH SHAKING) AND STATIC (WITHOUT SHAKING) CONDITIONS

\begin{tabular}{l|c|c}
\hline \multirow{2}{*}{ Sample } & \multicolumn{1}{c|}{$\begin{array}{c}\text { Aeration } \\
\text { conditions }\end{array}$} & Static conditions \\
\cline { 2 - 3 } & \multicolumn{2}{|c}{$\mathrm{U} / \mathrm{mL}$} \\
\hline $\begin{array}{l}\text { Addition of lignocellulose } \\
(0,5 \%)\end{array}$ & $3222.22 \pm 0.21$ & $1366.67 \pm 0.35$ \\
Addition of lignin $(0.5 \%)$ & $3111.11 \pm 0.43$ & $1611.11 \pm 0.12$ \\
Control sample & $3000.00 \pm 0.15$ & $1777.78 \pm 0.15$
\end{tabular}

The results represent the mean \pm standard deviation of at least three independent experiments.

aeration was 2.5 times higher than in the reference culture without addition of lignocellulose or lignin (Fig. 1).

In conditions of static growth without shaking, mycelium formed a dense film on the surface of liquid medium, which can be explained by the aerobic character of metabolism of L. edodes. In well aerated culture (shaking conditions) mycelium in liquid medium formed separate colonies resembling small beads.

Activity of laccase in cultivation medium increased with addition of wheat straw lignocellulose or lignin after mushroom mycelium growth for 28 days only in the case of cultivation with aeration (shaking conditions) (Table 2).

\section{Lentinula edodes mycelium growth on solid nutrient me- dia}

We also determined the effect of addition of kraft lignin to the solid nutrient medium (Fig. 2) on the growth of L. edodes mycelium on solid nutrient medium. Addition of kraft lignin in small amount $(0.1 \mathrm{~g}$ or $0.5 \%)$ during the first 14 days of cultivation resulted in slightly lower growth of mycelium, but there was no effect during the next 14 days. Addition of larger amounts $(0.5 \mathrm{~g}$ or $2.5 \%)$ of kraft lignin significantly suppressed growth of mycelium during the whole cultivation period. Cultivated on solid medium with addition of wheat straw lignocellulose obtained after furfural production or wheat straw lignin obtained after furfural and glucose production promoted growth of mycelium during the first seven days of cultivation (Table 3).

\section{DISCUSSION}

L. edodes is an edible mushroom with high value. It contains about $30 \%$ carbohydrates, $39 \%$ crude fibre, $17 \%$ crude protein, and $2 \%$ crude fat (Wang et al., 2014). Many beneficial medical uses of this mushroom for human health have been shown and reviewed during recent years. These include reduction of cholesterol, lowering of blood pressure, strengthening of the immune system, positive effects in application in anti-tumours treatment, and improvement of liver function (Bobek et al., 1991; Mau et al., 2002; Baba et

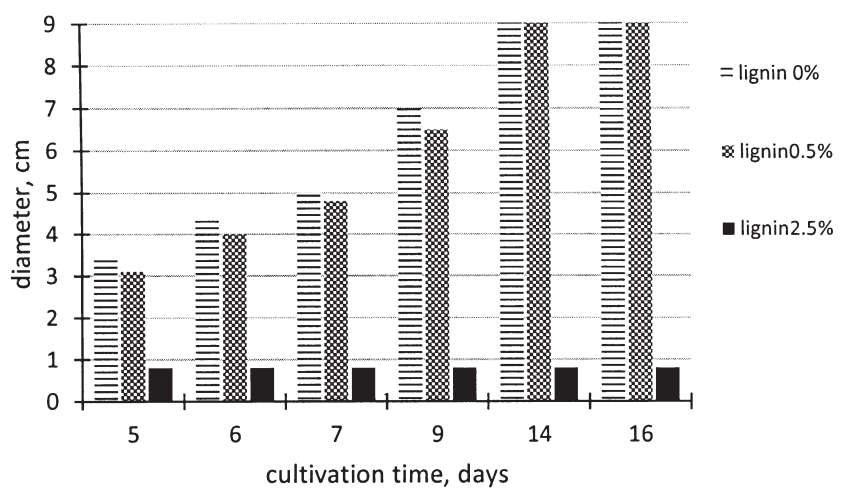

Fig. 2. Lentinula edodes mycelium diameter after growth on solid nutrient medium with addition of kraft lignin.

Table 3

EFFECT OF ADDITION OF 0.5\% WHEAT STRAW LIGNOCELLULOSE ON GROWTH OF LENTINULA EDODES MYCELIUM ON SOLID MEDIUM

\begin{tabular}{l|c|c|c}
\hline \multirow{2}{*}{$\begin{array}{c}\text { Nutrient } \\
\text { medium }\end{array}$} & \multicolumn{3}{|c}{ Mycelium diameter, cm } \\
\cline { 2 - 4 } \multicolumn{1}{c}{7 days } & 10 days & 12 days \\
\hline Control & $5.5 \pm 0.1$ & $7.9 \pm 0.1$ & $8.0 \pm 0.0$ \\
Addition of & $6.2 \pm 0.0$ & $7.8 \pm 0.1$ & $8.0 \pm 0.0$ \\
lignocellulose & & &
\end{tabular}

The results represent the mean \pm standard deviation of at least three independent experiments.

al., 2015). Improvement of human health by shiitake mushroom is usually explained by chemical compounds such as lentinan, eritadenine, and l-ergothioneine. It contains also anti-oxidants and vitamins A, C, D, E (Mau et al., 2002; Smith et al., 2002; Baba et al., 2015; Smith et al., 2015). Besides application for the improvement of human health this mushroom can be very efficiently used also in the feeding and veterinary treatment of various animals. For example, recently it was shown that fish diet supplemented with L. edodes mushroom extract improved immune response and disease resistance in rainbow trout and decreased mortality rate against Lactococcus garvieae (Baba et al., 2015). It is also known that L. edodes produces high amounts of hydrolases and oxidases for bioconversion of lignocellulosic wastes (Harris-Valle et al., 2014). There include manganese peroxidase, a number of oxidases and oxido-reductases like aryl alcohol oxidases and laccase (Harris-Valle et al., 2014).

Usually shiitake mushroom is cultivated on hardwood sawdust with grains as the nitrogen source (Royse, 1997; Rossi et al., 2003). It seems very interesting to use various agricultural wastes containing lignocellulose and/or lignin for $L$. edodes cultivation, as this would allow to simultaneously decrease the amount of wastes and to increase mushroom biomass yield using cheap substrates. This approach was applied in our current study. For cultivation of L. edodes we used lignocellulose and lignin which remained after furfural production (for its further use in the chemical industry) and after glucose obtainining (for the production, for example, of bioethanol as a fuel) from wheat straw. Cultivation of 
L. edodes mycelium in liquid nutrient medium with addition of $0.25-0.5 \%$ kraft lignin increased mycelium biomass yield by approximately two times compared with reference experiments without addition of lignin. Similar results were obtained in experiments in which we added to the nutrient medium $0.5 \%$ lignocellulose which remained after furfural production or $0.5 \%$ of lignin which remained after furfural and glucose production from wheat straw. This effect was stronger in cultivation with good aeration than in static culture. Laccase activity in the medium increased after addition of wheat straw lignocellulose or lignin only in the case of mycelium cultivation with aeration. In cultivation on solid nutrient medium, addition of wheat straw lignocellulose and lignin promoted growth of mycelium only in the first 7 days of cultivation.

There are few studies that can be compared with our results. Nevertheless, it was previously shown that lignin-derived phenols and polymeric lignin can promote growth of white-rot fungi, including L. edodes (Beltrán-García et al., 2001; Ferrara et al., 2002). Recently, addition of glucose and lignin in nutrient growth medium was shown to promote fungal growth and glucose was necessary for the manifestation of lignin growth-stimulating activity (Harris-Valle et al., 2014). We did not examine the effect of glucose in our study, but glucose was present in the used nutrient medium for the growth of L. edodes. It is not clear if lignin can be used by $L$. edodes as a carbon source or if it simply promotes growth (Harris-Valle et al., 2014). However, the observed significant increase of laccase activity after addition of lignocellulose or lignin to the nutrient medium suggest use of lignin as a carbon source. Of course, this should be tested in future experiments. Recently it was proposed that fungi can use lignin as a carbon source only in the case when it exists as a small polymer (Leisola et al., 2012). Therefore, in future experiments it would be interesting also to test if preliminary treatment of substrate material with lignin-modifying enzymes would facilitate lignin use for $L$. edodes growth. The main conclusion from this study is that lignocellulose and/or lignin which remain after production of different valuable substances from various cellulosecontaining waste substrates (Rapoport et al., 2014) can be also efficiently used for mushroom production and for the development of new completely waste-less technology.

\section{ACKNOWLEDGMENTS}

This work has been supported by the European Regional Development Fund project No. 2014/0026/2DP/2.1.1.1.0/ 14/APIA/VIAA/002.

\section{REFERENCES}

Baba, E., Uluköy, G., Öntaş, C. (2015). Effects of feed supplemented with Lentinula edodes mushroom extract on the immune response of rainbow trout, Oncorhynchus mykiss, and disease resistance against Lactococcus garvieae. Aquaculture, 448, 476-482.

Beltrán-García, M. J., Orozco, A., Samayoa, I., Ogura, T. (2001). Lignin degradation products from corn stalks enhance notable the radial growth of basidiomycete mushroom mycelia. J. Mexican Chem. Soc., 45, 77-81.
Bobek, P., Ginter, E., Kuniak, L., Babala, J., Jurcovicova, M., Ozdín, L., Cerven, J. (1991). Effect of mushroom Pleurotus ostreatus and isolated fungal polysaccharide on serum and liver lipids in Syrian hamsters with hyperlipoproteinemia. Nutrition, 7, 105-108.

Cotana, F., Cavalaglio, G., Nicolini, A., Gelosia, M., Coccia, V., Petrozzi, A., Brinchi, L. (2014). Lignin as co-product of second generation bioethanol production from ligno-cellulosic biomass. In: ATI $2013-68^{\text {th }}$ Conference of the Italian Thermal Machines Engineering Association, 11-13 September 2013. Elsevier Procedia, Perugia, Italy, pp. 52-60.

Ferrara, M. A., Bon, E. P. S., Neto, J. S. A. (2002). Use of steam explosion liquor from sugar cane bagasse for lignin peroxidase production by Phanerochaete chrysosporium. Appl. Biochem. Biotechnol., 98, 289-299.

Harris-Valle, C., Valenzuela-Soto, E., Sánchez, A., Gaitán-Hernández, R., Esqueda, M. (2014). Variability in the ligninolytic enzymes activity by Lentinula edodes in submerged culture with lignin and glucose. Amer. J. Agricult. Biol. Sci., 9, 369-378.

Kang, J. C. (2013). The risen of mushroom pharmaceutical industry. In: The $7^{\text {th }}$ International Medicinal Mushroom Conference 2013, 26-29 August 2013. Chinese Academy of Engineering, Beijing, China, pp. 826-834.

Leisola, M., Pastinen, O., Axe, D. D. (2012). Lignin-designed randomness. Bio-Complexity, 3, 1-11.

Matjuškova, N., Raipulis, J. (1999). Šitakē grāmata [Book on Shiitake]. Rota, Rīga. 100 lpp. (in Latvian).

Mau, J.-L., Lin, H.-C., Song, S.-F. (2002). Antioxidant properties of several specialty mushrooms. Food Res. Int., 35 (6), 519-526.

Niku-Paavola, M. L., Raaska, L., Itavaara, M. (1990). Detection of white-rot fungi by a non-toxic stain. Mycol. Res. 94 (1), 27-31.

Raaska, L. (1993). Cultivation and spawn production of the wood-decaying fungus, shiitake (Lentinula edodes). Optimization of spawn growth, production of degradative enzymes and interaction with wood inhabitants. VTT Publications, Vol. 157. Technical Research Centre of Finland, 84 pp.; see pp. $10-50$.

Rapoport, A., Vedernikov, N., Kruma, I., Puke, M., Borovikova, D., Rozenfelde, L., Khroustalyova, G., Matyuskova, N. (2014). Waste-less bioethanol and other valuable substances production from hardwood. WIT Transact. Eng. Sci., 88, 311-317.

Rossi, I. H., Monteiro, A. C., Machado, J. O., Andrioli, J. L., Barbosa, J. C. (2003). Shiitake Lentinula edodes production on a sterilized bagasse substrate enriched with rice bran and sugarcane molasses. Brazil. J. Microbiol., 34, 66-71.

Royse, D. J. (1997). Cultivation of shiitake on synthetic and natural logs. Available at: http://extension.psu.edu/publications/x10083/view (accessed 2 March 2017).

Salvachúa, D., Prieto, A., López-Abelairas, M., Lu-Chau, T., Martínez, A. T., Martínez, M. J. (2011). Fungal pretreatment: An alternative in second-generation ethanol from wheat straw. Bioresour. Technol., 102, 7500-7506.

Sasidharan, S., Aravindran, S., Latha, L. Y., Vijenthi, R., Saravanan, D., Amutha, S. (2010). In vitro antioxidant activity and hepatoprotective effects of Lentinula edodes against paracetamol-induced hepatotoxicity. Molecules, 15, 4478-4489.

Smith, H., Doyle, S., Murphy, R. (2015). Filamentous fungi as a source of natural antioxidants. Food Chem., 185, 389-397.

Smith, J., Rowan, N., Sullivan, R. (2002). Medicinal mushrooms: Their therapeutic properties and current medical usage with special emphasis on cancer treatments. Available at: http://www.academia.edu/305933/Medicinal_Mushrooms_Their_therapeutic_properties_and_current_medical_usa ge_with_special_emphasis_on_cancer_treatments (accessed 2 March 2017).

Sweeney, M. D. Xu, F. (2012). Biomass converting enzymes as industrial for fuels and chemicals: Recent developments. Catalysts, Biocatalysts, 2, 244-263. 
Sweeney, M. D., Xu, F. (2012). Biomass converting enzymes as industrial biocatalysts for fuels and chemicals: Recent developments. Catalysts, 2 (2), 244-263.

Turło, J., Gutkowska, B., Kałucka, M., Bujak, M. (2007). Accumulation of zinc by the Lentinus edodes (Berk.) mycelium cultivated in submerged culture. Acta Pol. Pharm., 64 (1), 45-51.

Received 27 August 2015

Accepted in the final form 28 January 2017
Wang, X.-M., Zhang, J., Wu, L.-H., Zhao, Y.-L., Li, T., Li, J.-Q., Wang, Y.-Z., Liu, H.-G. (2014). A mini-review of chemical composition and nutritional value of edible wild-grown mushroom from China. Food Chem., 151, 279-285.

Ward, G., Hadar, Y., Dosoretz, C. G. (2003). The biodegradation of lignocellulose by white rot fungi. In: Aurora, D. K. (ed.). Fungal Biotechnology in Agricultural, Food, and Environmental Applications. CRC Press, pp. 393-402.

\section{LIGNĪNU SATUROŠĀS BAROTNES IETEKME UZ ĀRSTNIECISKĀS SĒNES LENTINULA EDODES AUGŠANU}

Darbā tika izpētīta lignocelulozes un lignīna ietekme uz sēnes Lentinula edodes micēlija augšanu un lakkāzes aktivitāti kultivēšanas barotnē. Konstatēts, ka $L$. edodes micēlija kultivēšana šķidrajā barotnē, kurai pievienots $0,25-0,5 \%$ kraft-lignīns, palielināja biomasas iznākumu vidēji divas reizes, salīdzinot ar kontroles eksperimentiem bez lignīna pievienošanas. Līdzīgi rezultāti tika iegūti eksperimentos, kuros $0,5 \%$ kviešu salmu lignoceluloze pēc furfurola atdalīšanas, vai $0,5 \%$ kviešu salmu lignoceluloze pēc furfurola un glikozes atdalīšanas, tika pievienotas kultivēšanas barotnei. Minētais efekts bija izteiktāks gadījumā, kad notika kultivēšana ar labu aerāciju, salīdzinot ar statiski audzētu kultūru. Pēc kviešu salmu lignocelulozes vai lignīna pievienošanas lakkāzes aktivitāte barotnē palielinājās tikai gadījumā, kad micēlijs tika kultivēts, pielietojot aerāciju. Pētījumos par sēṇu kultivēšanu uz cietās barotnes novērots, ka kraft-lignīna, kā arī kviešu salmu lignocelulozes vai lignīna pievienošana aktivēja micēlija augšanu tikai pirmajās 7-14 kultivēšanas dienās. 